\title{
Seating Spaces in Scandinavian Mesolithic Dwellings
}

\section{O. Grøn}

For citation: Grøn O. Seating Spaces in Scandinavian Mesolithic Dwellings. Vestnik of Saint Petersburg University. History, 2021, vol.66, issue 3, pp. 890-908. https://doi.org/10.21638/11701/spbu02.2021.312

The analysis of positioning patterns for individuals in Mesolithic dwellings presented here is based, on the one hand, on ethnographic data on hunter-gatherer culture-specific patterns for the placing of individuals in the dwelling space and, on the other, on observations in the excavated archaeological record of repetition in the spatial organisation of small artefact concentrations, hearths etc. in the well-preserved remains of Mesolithic dwellings. In addition to the latter spatial organisational patterns, zones containing relatively low densities of debitage have also, in a couple of cases, been seen to coincide with the proposed positions of individuals, as indicated by the 'positive' activity indicators. It has been suggested that these so-called 'seating spaces' are indicative of the fact that individuals seated in a dwelling kept their seating positions free of smaller pieces of waste. They possibly achieved this by sitting on some form of underlay - a small mat of skin or bark - that could easily be cleaned off while they drew to their seating positions larger pieces of debitage that were useful as tools for cutting, shaping etc. Based on data from several well-documented Mesolithic sites, this paper investigates this latter aspect further as a potentially independent way of checking the results of the first phase of distribution analysis of the Mesolithic dwellings. In general, recent excavations incorporating systematic recording of the flint debitage appear to produce meaningful results, while earlier excavations, where this category was recorded in less detail — often just being counted and discarded - tend not to.

Keywords: spatial analysis, ethnoarchaeology, Mesolithic archaeology, dwellings, stone age, hunter-gatherer, organizational symbolism.

\section{Места для сидения в мезолитических жилищах Скандинавии}

О. Грюн

Для цитирования: Grøn O. Seating Spaces in Scandinavian Mesolithic Dwellings // Вестник СанктПетербургского университета. История. 2021. Т. 66. Вып. 3. С. 890-908.

https://doi.org/10.21638/11701/spbu02.2021.312

Представленный в работе анализ моделей размещения людей в мезолитических жилищах основан, с одной стороны, на этнографических данных о моделях размещения людей в жилищном пространстве, специфических для культур охотников-собирателей, а с другой - на наблюдениях за повторяемостью пространственной организации небольших скоплений артефактов, очагов и прочих материальных свидетельств в хорошо сохранившихся остатках мезолитических жилищ, выявляемых при археологиче-

Ole Grøn - PhD, Research Scientist, University of Copenhagen, 10, Østervoldgade, Copenhagen K, DK 1250, Denmark; olegron111@gmail.com

Оле Грюн - PhD, науч. сотр., Копенгагенский университет, Дания, DK 1250, Копенгаген К, Остервольдгаде, 10; olegron111@gmail.com

(C) St. Petersburg State University, 2021 
ских раскопках. В схемах пространственной организации археологического материала в отдельных случаях были также отмечены зоны с относительно низкой плотностью продуктов расщепления камня. Предположительно, они могут совпадать с возможной локализацией обитателей жилищ, на что указывают «положительные» индикаторы активности. Высказано предположение, что существование так называемых мест для сидения означает, что люди, сидевшие в жилом помещении, не допускали попадания мелкого мусора на занятое место. Возможно, этому способствовало наличие некой формы подложки для сидения в виде небольшого мата из древесной коры или шкуры животного, которую можно было легко очистить в момент, когда они перемещали к рабочим площадкам крупные осколки или фрагменты каменного материала, которые могли быть использованы для производства инструментов для резки, переоформления изделий и т.д. На основании данных из нескольких мезолитических поселений с хорошо задокументированными чертами пространственного распространения археологического материала эта статья исследует указанный аспект как потенциально независимый способ проверки результатов первой фазы анализа распределения археологического материала из мезолитических жилищ. В целом недавние раскопки, включающие систематическую регистрацию мелких осколков, отщепов и чешуек кремня, по-видимому, дают значимые результаты для планиграфического анализа, в то время как более ранние раскопки, где находки мелкого дебитажа регистрировались менее подробно (в ряде случаев просто подсчитывались и выбрасывались), как правило, таких результатов не давали.

Ключевые слова: пространственный анализ, этноархеология, археология мезолита, жилище, каменный век, охотники-собиратели, символика организации.

\section{Introduction}

During the 1980s and 1990s, it became clear that the Mesolithic archaeological record of northern Europe offers an interesting opportunity for the adoption of an 'ethnographic' approach to its interpretation. The repetitive and culture-specific spatial patterns of hearths and some key activity areas inside well-preserved Mesolithic dwelling structures indicate that the dwelling space was organised in accordance with culture-specific rules of the same character as those employed by apparently all small-scale cultures known today (Fig. 1) ${ }^{1}$. The interesting thing about dwellings is that their spatial organisation reflects an everyday situation in the lives of the smallest groups within these cultures. The traces of their activities can therefore potentially record key information about the individuals' social relations and the group's social organisation, where the deposition of waste, cleaning routines and other elements of the site formation processes allow the preservation of such patterns.

Once such spatial-behavioural sets had been recognised in the context of well-preserved dwelling remains, they also began to be identified in excavated contexts where no structural dwelling remains were observed. Re-excavation of some of these sites, together with the scrutinisation of old excavation reports about preserved dwelling features

1 Grøn O.: 1) A method for reconstruction of social organization in prehistoric societies and examples of practical application. Social Space // Proceedings of an Interdisciplinary conference on human spatial behaviour in dwellings and settlements. Odense, 1991. P. 100-117; 2) The Maglemose Culture. The reconstruction of the social organization of a mesolithic culture in Northern Europe. Oxford, 1995; 3) Mesolithic dwelling places in south Scandinavia: their definitions and social interpretation // Antiquity. 2003. Vol. 77 (298). P. 685-708; 4) Interdisciplinary reflections on repetitive distribution patterns in Scandinavian Mesolithic dwelling spaces // Journal of Archaeological Science: Reports. 2018. Vol. 18. P.925-935. 
Maglemose

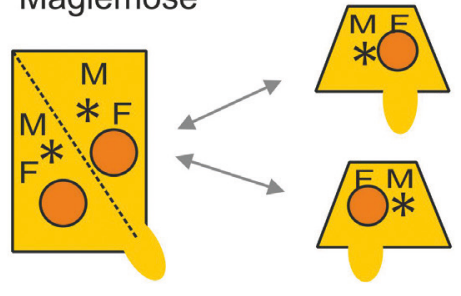

Kongemose - Ertebølle

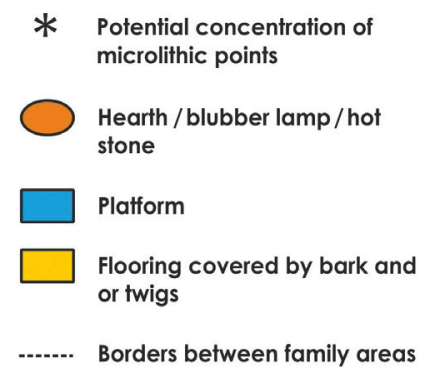

M Suggested male day positions?

F Female positions?
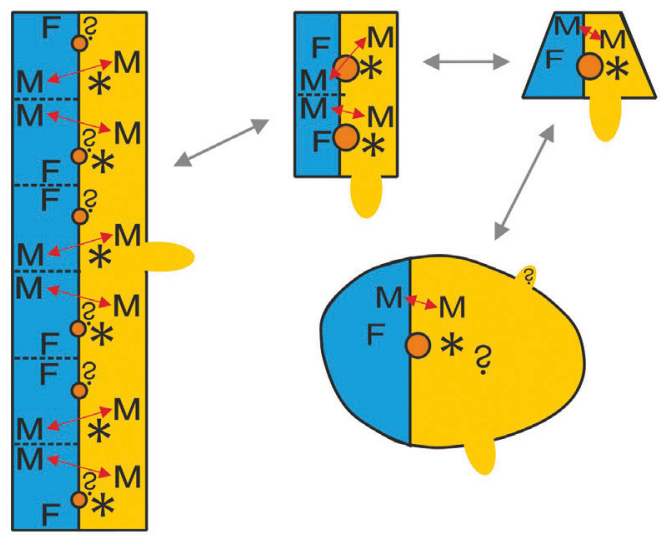

Fig. 1. The standardised spatial positions of hearths / blubber lamps / heated stones as well as concentrations of microlithic points when such are observable in the singleand multi-family dwellings of the Early Mesolithic Maglemose culture (upper) and the Late Mesolithic Kongemose and Ertebølle cultures (lower). The male and female day positions have been reconstructed on this basis, with the Late Mesolithic males switching between a knapping position on the dwelling floor and a seating position on the platform. The married couples are assumed to have slept together on the platforms during the night, as in the case of, for instance, the Siberian Evenk. Positions of children have so far not been convincingly identified (Grøn O.: 1) The Maglemose Culture; 2) Mesolithic dwelling places in south Scandinavia. P.685-708; Molin F., Hagberg L., Westermark A. Living by the shore: Mesolithic dwellings and household in Motala, eastern central Sweden, 5600-5000 cal. BC // Journal of Archaeological Science: Reports. 2018. Vol.18. P.913-924.). The interpretation of the Ertebølle longhouse at Tågerup (Cronberg C. Husesyn // Tågerup specialstudier. Riksantikvarieämbetet, 2001. P. 82-155.) as a six-family unit is the result of further analysis of the excavation data. The heating sources here are thought to have been heated stones or blubber lamps. Graphics: O. Grøn

not recognised as such during the excavation, led to the detection of a number of 'new' Mesolithic dwelling structures at these previously investigated sites. Several previously unrecognised shallow dwelling pits became evident, and central internal posts were observed in association with the two dwelling features at Flaadet and Svanemosen $28^{2}$.

The approach presented here can be perceived as a spinoff resulting from the generally increasing focus on Mesolithic dwellings from the 1970s onwards, accompanied by

${ }^{2}$ Grøn O. The Maglemose Culture. P. 12, 36-37, 48-50, 60, 69, 75-76, 79, 82. 
a better understanding of their concomitant features. It has also led to the recognition of further Mesolithic dwellings during more recent excavations ${ }^{3}$.

In the case where no, or only faint, indications of preserved physical dwelling features or diagnostic activity features are found, it would be useful to have an independent check of the validity of the distribution analysis of the activity zones and hearths. The first attempt to establish 'seating spaces' as just such an indicator (Fig. 2) took place in 1987, in support of the interpretation of the spatial organisation of the presumed large Maglemose winter house at the Flaadet site. A similarly organised series of 'seating spaces' was subsequently identified in the Maglemose dwelling pit at Svanemosen $28^{4}$. This approach has also been applied with reasonable success to a couple of Late Mesolithic sites: the submerged and exceptionally well-preserved Early Ertebølle dwelling at Møllegabet II $^{5}$ and the Ertebølle longhouse at the Tågerup site in Sweden ${ }^{6}$. All four sites have rather high densities of lithic debitage within the areas interpreted as dwelling spaces, which is

${ }^{3}$ See e. g.: Bagniewski Z. Obozowisko mezolityczne we wsi Siedlisko, woj. zielonogórskie, stan. 16 // Światowit. 1982. Vol. XXXV. P. 5-54; Bērziņš V. Sārnate: Living by a Coastal Lake During the East Baltic Neolithic. Oulu, 2008. P. 51-61, 275-330; Clarke D. V., Sharples N. Settlements and Subsistence in the Third Millenium BC // The Prehistory of Orkney. Edinburgh, 1990. P.54-82; Conneller C., Milner N., Taylor B., Taylor M. Substantial settlement in the European Early Mesolithic: new research at Star Carr // Antiquity. 2012. Vol. 86 (334). P. 1004-1020; Grøn O.: 1) Aggemose - part II. Refitting and indications of wall effect // Journal of Danish Archaeology. 1994. Vol. 12. P.7-12; 2) The Maglemose Culture; Grøn O., Sørensen S. An inland site from the early Kongemose Culture // Journal of Danish Archaeology. 1993. Vol.11(1). P.7-18; Hernek $R$. Nytt ljus på Sandarnekulturen. Om en boplats från äldre stenåldern i Bohuslän. Göteborg, 2005; Karsten P., Knarrström B. The Tågerup Excavations. Lund, 2003; Katiskoski K. The semisubterranean dwelling at Karmelahti in Puumala, Savo province, eastern Finland // Huts and Houses: Stone Age and Early Metal Age Buildings in Finland. Jyvaskyla, 2002. P. 171-200; Kind C.-J. Einraum-Wohnung mit Aussenlage: Das grosse Mesolithische Hauptlager aus dem Horizont III von Siebenlinden // Pleistocene Foragers: Their Culture and Environment. Festschrift in Honour of Gerd-Christian Weniger for his Sixtieth Birthday. Vol.6: Mettmann. [N.1.], 2013. P. 133-162; Larsson L.: 1) A contribution to the knowledge of Mesolithic huts in southern Scandinavia. Meddelande från Lunds Universitets Historiske Museet 1973-74. Lund, 1975. P. 5-28; 2) Of House and Hearth. The Excavation, Interpretation and Reconstruction of a Late Mesolithic House // Archaeology and Environment. 1985. Vol.4. P. 197-209; Larsson L., Sjöström A. Hut and House Structures in the Mesolithic of Southern Scandinavia. Site-internal spatial organization of hunter-gatherer societies: Case studies from the European Palaeolithic and Mesolithic // Site-internal spatial organization of hunter-gatherer societies: Case studies from the European Palaeolithic and Mesolithic. Papers submitted at the session (C58). "Come in ... and find out: Opening a new door into the analysis of hunter-gatherer social organisation and behaviour", held at the $15^{\text {th }}$ U. I. S. P. P. Conference in Lisbon, September 2006. Mainz, 2011. P. 233-247; Lass Jensen O. Dwellings and graves from the Late Mesolithic site of Niva 10, eastern Denmark // Mesolithic Horizons. Vol. I. Oxford, 2009. P.465-472; Molin F. Along the shores of the Ancylus Lake. Trädgardstorp and other coastal Mesolithic settlement sites during the Late Ancylus period in western Östergötland // Ibid. P.458-464; Ramstad M. Island settlements and maritime hunter-fishers: spatial and temporal transformations over 11,000 years at Melkøya, northern Norway // Mesolithic Horizons. Vol.I. Oxford, 2009. P. 422-429; Skaarup J., Grøn O. Møllegabet II. A submerged Mesolithic settlement in southern Denmark. BAR International Series 1328. Oxford, 2004; Sørensen S. A.: 1) A Maglemosian Hut at Lavringe Mose, Zealand // Journal of Danish Archaeology. 1988. Vol.6. P.53-62; 2) Lollikhuse - a Dwelling Site under a Kitchen Midden // Journal of Danish Archaeology. 1995. Vol. 11. P. 19-29; Engelstad E. The Iversfjord locality. A study of behavioral patterning during the late Stone Age of Finnmark, North Norway. Tromsø, 1981; Wenzel S. Behausungen im Späten Jung-paläolithikum und im Mesolithikum in Nord-, Mittel- und Westeuropa. Mainz, 2009; Åstveit L. I. Different ways of building, different ways of living: Mesolithic house structures in western Norway // Mesolithic Horizons. Vol. I. Oxford, 2009. P.415-421.

${ }^{4}$ Grøn O.: 1) Seasonal variation in Maglemosian group size and structure: A new model // Current Anthropology. 1987. Vol. 28 (3). P. 303-327;2) Analyse af flintspredninger på bopladser (chapter of university text book) // Flintstudier. En håndbog i systematiske analyser af flintinventarer. Århus, 2000. P. 157-186.

${ }^{5}$ Skaarup J., Grøn O. Møllegabet II. P. 42-74.

${ }^{6}$ Cronberg C. Husesyn. P. 82-155. 


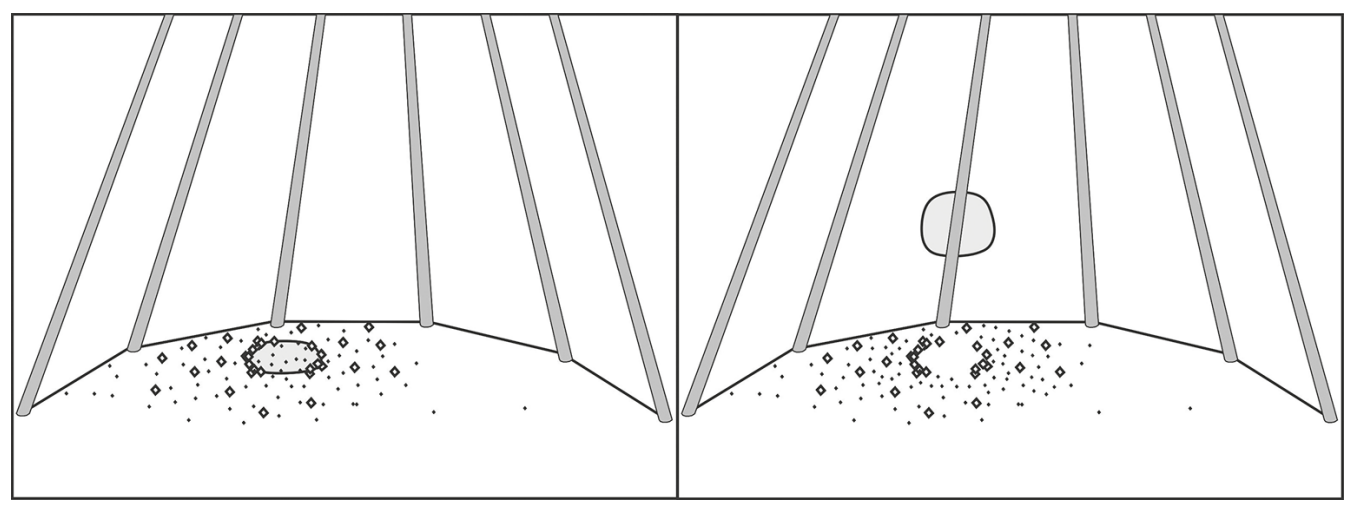

Fig. 2. Explanation of how seating spaces can develop. Left: When a person uses a sitting mat sitting on or just being around it - smaller pieces of lithic debitage are spread around and over the mat. Larger pieces of debitage collect immediately around the mat - or possibly just under its edge because they are used in the working processes carried out there, such as the production of knives, borers, etc. Right: When the person occupying this position is absent for some time, the sitting mat will normally be cleared of waste and, in a tent, be typically stored behind a tent pole, leaving a small space with higher relative density of larger debitage pieces than its immediate surroundings. Small black dots: smaller pieces of debitage. Large squares: larger pieces of debitage. Graphics: O. Grøn

probably why the seating spaces are rather easy to distinguish in these cases. At sites with less debitage, it can be difficult or even impossible to identify the seating spaces or other spatial features ${ }^{7}$.

It should be noted that many sites and dwellings are most likely virtually invisible due to their complete lack of flint or the extremely restricted occurrence of artefacts of this durable material. A good example of this is the Hjemsted dwelling pit $^{8}$.

It should also be noted that the occurrence of strict spatial patterns within a Mesolithic dwelling does not necessarily mean that this represents a 'short-term' habitation. A dwelling structure investigated by Oleg Kuznetsov and by the author of the article in Siberia had been used annually for approximately 40 years by three different families, who apparently employed the same basic internal spatial patterns ${ }^{9}$.

\section{The sites in focus}

This section presents the four sites, all of which had significant densities of debitage, which are the focus of this paper. The Flaadet site from the Early Maglemose culture was excavated in $1973^{10}$ and, based on the spatial organisation of its microliths, scrapers and

${ }^{7}$ Grøn O. Bum-spaces in Mesolithic debitage distributions - Positions adopted by individuals in dwellings as indicated by artefact concentrations // Studies dedicated to prof. Lucyna Domanska at the $45^{\text {th }}$ anniversary of her scientific and didactic work and on her 70 ${ }^{\text {th }}$ birthday. Lodz, 2018. P. 73-87.

8 Grøn O., Peeters H. Mesolithic 'ghost' sites and related Stone Age problems with lithics // Foraging Assemblages Vol. 1. New York, 2021. P. 233-239.

9 Grøn O., Kuznetsov O. Ethno-archaeology among Evenkian forest hunters. Preliminary results and a different approach to reality! // Mesolithic on the Move. Papers presented at the Sixth International Conference on the Mesolithic in Europe. Stockholm; Oxford, 2003. P. 216-221.

10 Skaarup J. Flaadet. En tidlig maglemoseboplads på Langeland. Langeland. 1979. P. 9-11, 37-104. 
hearths, is interpreted as a 6-7 $\times 8 \mathrm{~m}$ log-built winter house for two families ${ }^{11}$. Fifteen of the 110 core axes that were analysed for micro-wear traces proved to have been predominantly used for light work - most likely whittling or planing of wood and/or bark with marked abrasive properties ${ }^{12}$. This is consistent with the preparation of logs for the construction of a log cabin. Only one of the 22 analysed axes showed evidence of heavy edge damage ${ }^{13}$. Re-excavation of the site in 1989, after the material had been subjected to spatial analysis, revealed four postholes running in a line exactly from one gable of the postulated dwelling structure to the other (Fig. $3 \mathrm{~B})^{14}$. A burnt log cabin of this size, with a period of use dated to 3500-2500 cal BC, has been reported from the Finish hunter-gatherer Neolithic ${ }^{15}$, so cabins of this kind may extend far back in time. The Flaadet site was excavated and the debitage recorded in $1 \mathrm{~m}^{2}$ squares $^{16}$.

The Svanemosen 28 site comprises the remains of a Late Maglemose dwelling with a shallow (25-30 cm deep), rectangular dwelling pit measuring $6 \times 4 \mathrm{~m}$. It contains four postholes along an irregular centre line, and based on its size and the distribution pattern identified within it (microliths, scrapers, and hearths), it is interpreted as a typical two-family unit for habitation during the summer half of the year. Because the main part of the dwelling was excavated in $1 \mathrm{~m}^{2}$ squares, and only its southern part in $0.25 \mathrm{~m}^{2}$ squares, the site has been analysed on the basis of its $1 \mathrm{~m}^{2}$ densities (Fig. $\left.3 \mathrm{D}\right)^{17}$.

A $5 \times 3 \mathrm{~m}$ oval dwelling at the submerged Early Ertebølle site of Møllegabet II was excavated in 1993 at a depth of $4.5 \mathrm{~m}$ off Ærøskøbing in the South Funen Archipelago. There was a 15-20 cm deep dwelling pit with the lower parts of five wall stakes and two internal stakes preserved. After the dwelling pit had been dug, an approximately $10-15 \mathrm{~cm}$ high earthen platform was built in its northern half. Remains of what appears to have been a bark cover, consisting of numerous smaller fragments, was preserved on top of it. A twisted bundle of thin hazel branches was preserved along a short section of the platform front. The two inner stakes were positioned exactly at the platform front and could therefore have been cut off at the top level of the platform and served as supports for its front, together with the twisted bundle ${ }^{18}$. Similarly positioned internal stakes have recently been found in Sweden ${ }^{19}$. The dwelling was excavated in $0.25 \mathrm{~m}^{2}$ squares and analysed based on this unit. It had two significant concentrations of Late Mesolithic oblique and transverse arrowheads on the floor below the platform. These conjoined with two concentrations of debitage with more than 2000 pieces per $0.25 \mathrm{~m}^{2}$ square - apparently areas where flintknapping was carried out. Traces of two hearths were observed between the concentrations of arrowheads and the platform (Fig. 5) ${ }^{20}$.

11 Grøn O.: 1) Studies in Settlement Patterns and Submarine Bogs: Results and Strategy for Further Research. Contributions to the Mesolithic in Europe. Papers Presented at the Fourth International Symposium 'The Mesolithic in Europe', Leuven 1990. Leuven, 1990. P. 81-86; 2) The Maglemose Culture. P. 34-60, 81-82.

12 Symens N. Report on Microwear Analysis on the Flaadet Material. Unpublished report. 1985.

13 Grøn O. Seasonal variation in Maglemosian group size and structure. P. 303-327.

14 Grøn O.: 1) Studies in Settlement Patterns... P. 81-86; 2) Mesolithic dwelling places in south Scandinavia. P. 685-708.

15 Katiskoski K. The semisubterranean dwelling... P. 171-200.

16 Skaarup J. Flaadet. P. 35-36.

17 Grøn O. The Maglemose Culture. P. 34-60, 73-76.

18 Skaarup J., Grøn O. Møllegabet II. P. 41-74.

19 Molin F., Hagberg L., Westermark A. Living by the shore. P.913-924.

${ }^{20}$ Skaarup J., Grøn O. Møllegabet II. P. 41-74. 


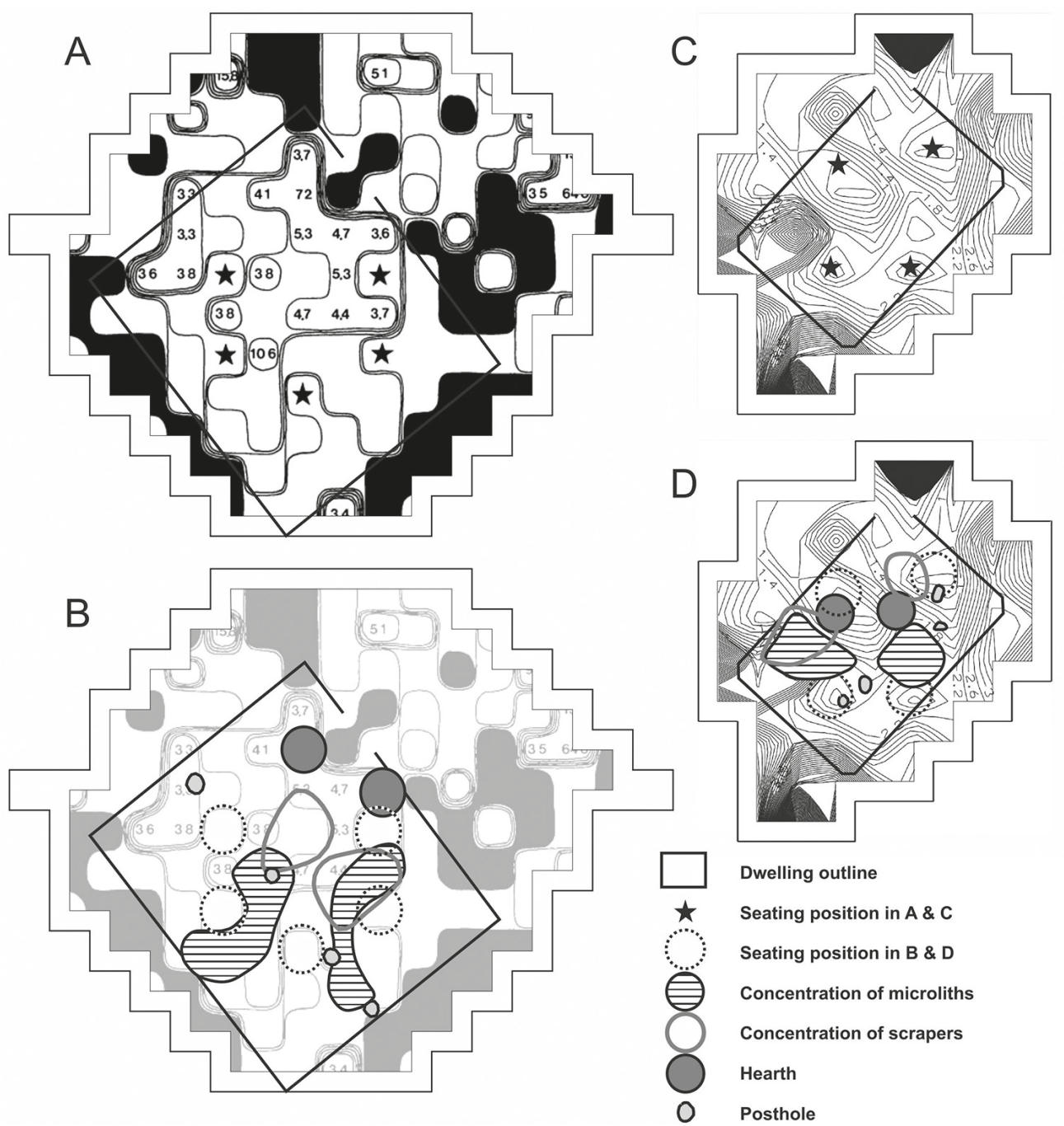

Fig. 3. The separately published results of analyses of seating positions in the Maglemose dwellings at Flaadet and Svanemosen 28. A: Shows the originally published interpolation with hand-drawn equidistant contour lines for the values 1,2 etc. of the quotient $\mathrm{Q}_{1}=($ microblades $\times$ flakes $) /(\text { blades })^{2}$, for Flaadet. Local minima assumed to represent the positions of seated individuals (person positions) in the dwelling space are marked with stars. C: Shows the originally published interpolation with equidistant contour lines for the values 0.0, 0.2, 0.4 etc. of the same quotient for Svanemosen 28 (the interpolation was produced here with the program 'Surfer' from Golden Software). The local minima are marked with stars. B and D: Show these indicated seating positions in relation to the symmetrical arrangements of concentrations of microliths, concentrations of scrapers, hearths and postholes, at the same two sites (Grøn O.: 1) Seasonal variation in Maglemosian group size and structure. P.303-327; 2) Analyse af flintspredninger på bopladser (chapter of university text book). P.157-186). Graphics: O. Grøn 
Tågerup house 2 (A7681), the so-called 'longhouse', was excavated in 1995-199921. It belongs to the earlier part of the Ertebølle culture and comprises a $16.5 \mathrm{~m}$ long and $7.5 \mathrm{~m}$ wide cultural deposit varying in thickness from $1 \mathrm{~cm}$ peripherally to $20 \mathrm{~cm}$ in its central parts. It contained a $13 \mathrm{~m}$ long and $0.8-1.7 \mathrm{~m}$ wide stone packing, a ditch structure in its eastern end and several postholes. The construction and shape of the dwelling is not immediately obvious from the finds. The remains have been interpreted in two different ways, both of which suggest a longhouse measuring as much as c. $14 \times 6-7 \mathrm{~m}$. The structure was excavated in $0.25 \mathrm{~m}^{2}$ squares, and its analysis is based on this unit ${ }^{22}$. The data have recently been re-examined by the author of the article in accordance with a new analysis of the excavation database kindly provided by Mathilda Kjällquist. This has resulted in a reinterpretation of this feature as the remains of a $17 \times 4$ m longhouse (Fig. 6).

\section{The detection of seating spaces in lithic distributions}

Debitage can be recorded in different ways. It is often recorded as counts of blades, flakes, microblades and waste per $1 \mathrm{~m}^{2}$ or $0.25 \mathrm{~m}^{2}$ square, and sometimes in size categories for each unit square. If the weight of the various debitage categories has been recorded per square unit, this is normally useful for the detection of seating spaces. Seating spaces are small areas where the debitage is dominated by larger, heavier pieces and therefore displays a greater average weight than the immediately adjacent squares (Fig. 2). Detection of such areas can be undertaken in several different ways. In principle, any formula that can display such a variation may be employed. The way the debitage has been categorised is of course determining for the type of formula that can be used in the analysis. Due to differences in the composition of the debitage produced by different cultures (microblades, absence of microblades, etc.) some types of formula are more conducive to analysing some cultural groups rather than others. It is simply a question of testing out different formulas and gaining experience in which formula or formulas work best with the material being analysed. The aim is to visualise the seating spaces graphically in the optimal way. To amplify the features, the counter and/or the denominator of the fraction can be raised to the second or the third power. When such operations do not produce a clearer image, however, it is better to keep the formula as simple as possible.

Once the debitage counts and/or weight data have been loaded into a spreadsheet, it is rather simple to test how different formulas work using the spreadsheet's column-calculation function. The resulting quotients can be displayed in relation to the squares they represent, by hand drawing of the interpolated lines (Fig. $3 \mathrm{~A}$ ) or by using an interpolation program such as 'Surfer' from Golden Software (e. g. Fig. 3 C).

Sometimes, it is only possible to detect a seating space as an 'indentation' in an area with high quotient values (e. g. the upper right example in Fig. 4 B). If the other seating spaces appear as clear features and their positions generally fit with - and confirm the established spatial organisational pattern for the dwellings of a specific culture, this 'indentation' should be accepted. Apart from the seating spaces in the 'fixed' positions of a dwelling space, similar features can also appear, i. e. concentrations potentially reflecting the storage of larger pieces of debitage (blades, knives etc.) or the presence of

${ }^{21}$ Larsson R. Inledning // Tågerup specialstudier. Riksantikvarieämbetet, 2001. P.15-31.

${ }^{22}$ Cronberg C. Husesyn. P. 82-155. 
other persons (older children, grandparents etc.) with a permanent spatial position in the household. Such seating positions have so far not been convincingly related to identifiable additional activity areas.

For the Maglemose sites of Flaadet and Svanemosen 28 the formula

$$
\mathrm{Q}_{1}=(\text { microblades } \times \text { flakes }) /(\text { blades })^{2},
$$

was used to calculate the quotient, $\mathrm{Q}_{1}$, per $\mathrm{m}^{2}$ (Fig. 3). As the microblades and flakes are generally smaller than the blades, this quotient will decrease when there are relatively fewer smaller pieces (microblades and flakes) in relation to relatively more abundant larger pieces (blades). Both these Maglemose sites had first been analysed for distribution patterns typical of a dwelling unit. In the case of Flaadet, the dwelling area was distinguished analytically as a 6-7 $\times 8 \mathrm{~m}$ rectangular area, with the typical artefact and hearth pattern of a large two-family Maglemose dwelling, which was suggested to have been a winter house. This conclusion was subsequently corroborated by the results of a post-analysis re-excavation of the site, where four postholes were observed along a central line running from gable to gable (Fig. $3 \mathrm{~A}, \mathrm{~B}$ ). These had been difficult to see during the main excavation (Fig. $3 \mathrm{~B})^{23}$. The $6 \times 4 \mathrm{~m}$ dwelling pit at Svanemosen 28 also had the typical organisational pattern of a Maglemose two-family dwelling (Fig. $3 \mathrm{D}$ ). In both cases, the four detected seating spaces matched the seating positions indicated by the spatial organisation of the concentrations of microliths and scrapers, together with the hearths (Fig. $3 \mathrm{~B}, \mathrm{D})^{24}$.

Two areas on the eastern and western peripheries of the Flaadet dwelling are interesting: with their low relative density of smaller debitage categories, they may represent family sleeping areas. The already suggested entrance ${ }^{25}$ stands out as a zone with extremely low quotient values, possibly due to traffic in and out of the dwelling.

It should be noted that the two concentrations of scrapers at Svanemosen $28-$ and especially that to the north - are not statistically significant in themselves. But the presence of weak local minima centrally in relation to the scraper distribution reinforces the significance of the pattern.

A formula that appears to work better for several other Maglemose sites is,

$$
\mathrm{Q}_{2}=(\text { waste } \times \text { microblades } \times \text { flakes }) /(\text { blades })^{3},
$$

where 'waste' is the debitage not included in the categories of blades, microblades and flakes (e. g. Fig. 4). This formula seems to render the seating spaces more visibly than the first one given above (Fig. 4 A, B).

It seems that simpler formulas work well for the Late Mesolithic Ertebølle culture, where there was no systematic production of a smaller category of debitage, such as microblades, than for the Maglemose culture, where the production of microblades is a diagnostic feature. In the case of the submerged Early Ertebølle site of Møllegabet II, the debitage was categorised by size in $2 \mathrm{~cm}$ intervals, $0<2 \mathrm{~cm}$ (A pieces), $2<4 \mathrm{~cm}$ (B pieces), $4<6 \mathrm{~cm}$ (C pieces) and $\geq 6 \mathrm{~cm}$ (D pieces). The quotient first calculated here per $0.25 \mathrm{~m}^{2}$ square was,

${ }^{23}$ Grøn O.: 1) Seasonal variation in Maglemosian group size and structure. P.303-327; 2) The Maglemose Culture. P. 19-95.

${ }^{24}$ Grøn O.: 1) The Maglemose Culture. P. 19-95; 2) Analyse af flintspredninger på bopladser (chapter of university text book). P. 157-186.

${ }^{25}$ Grøn O. Seasonal variation in Maglemosian group size and structure. P. 303-327. 


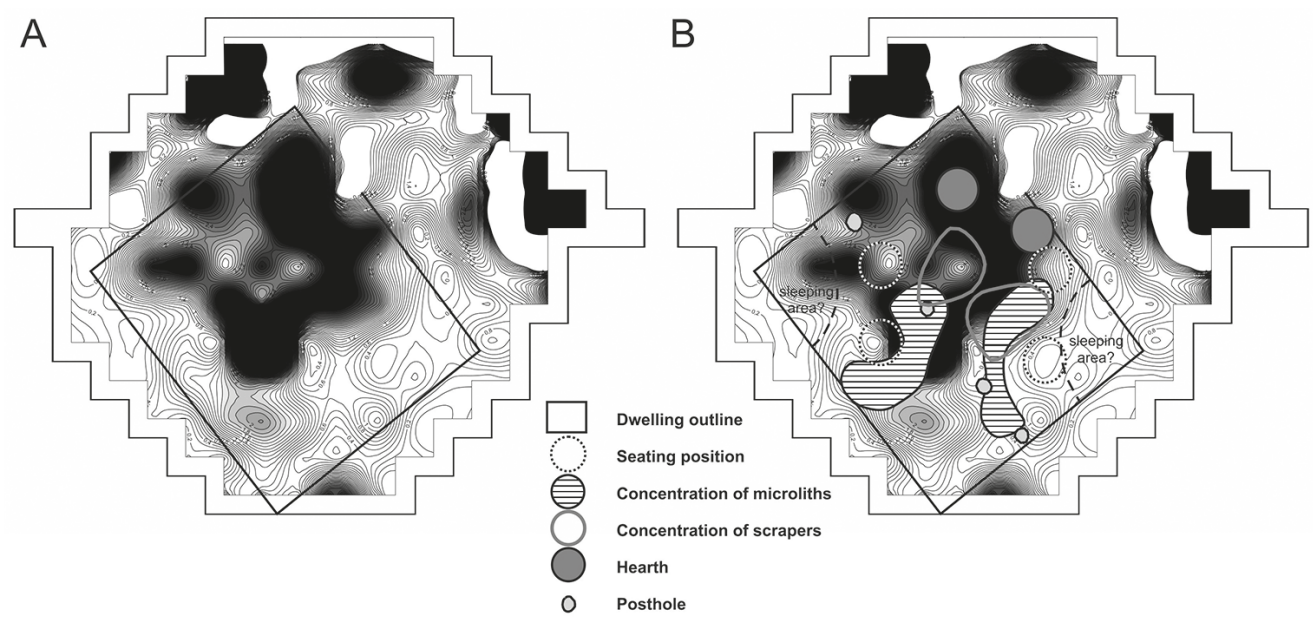

Fig. 4. The Flaadet site. A: The values produced by calculating the quotient $\mathrm{Q}_{2}=($ waste $\times$ microblades $\times$ flakes $) /(\text { blades })^{3}$ and interpolated with equidistant contour lines for the values $0.1,0.2$ etc. $\mathrm{B}$ : The spatial relationships of the presumed dwelling, the indicated seating positions, the concentrations of microliths, the concentrations of scrapers, the hearths and the postholes (modified from [Grøn O. Bum-spaces in Mesolithic debitage distributions... P. 73-87]). Graphics: O. Grøn

$$
\mathrm{Q}_{3}=(\mathrm{A} \text { pieces }) /(\mathrm{B}+\mathrm{C}+\mathrm{D} \text { pieces }),
$$

which produced seven seating spaces, of which four matched the central positions identified via the previous analysis of artefact and hearth distributions, and two are interpreted as male positions on the platform - connected to the male floor positions by red arrows (Fig. $5 \mathrm{~A}, \mathrm{~B})^{26}$.

The question was whether this could be simplified further, for instance, to the average weight of the debitage per $0.25 \mathrm{~m}^{2}$ square,

$$
\mathrm{Q}_{4}=\mathrm{G} /(\text { A pieces }+\mathrm{B} \text { pieces }+\mathrm{C} \text { pieces }+\mathrm{D} \text { pieces }) \text {, }
$$

where $\mathrm{G}$ is the total debitage weight per square. As shown in Fig. 5, the quotient $\mathrm{Q}_{4}$ produces a result that is not as clear and distinct as $\mathrm{O}_{3}$, but with the minima of the latter more or less matching the maxima of the former and also producing a plausible seating situation in relation to the other features. Two smaller maxima, which are closely related spatially to the two hearth areas of the dwelling (Fig. 5 C, D), are interpreted as hearth-related features. It is unlikely that there could be a seating position here so close to a hearth. These features may have been caused by the clearing out of the hearth zone, exchange of material in relation to it etc.

Inverting the quotient, $\mathrm{Q}_{4}$, to turn the maxima into minima, like in the former quotients, gives a more blurred picture in relation to the other features, which is why the present version has been chosen. It is interesting that a size fractioning of the debitage appears to produce a more distinct image of the prehistoric seating situation than a weight frac-

${ }^{26}$ Based on: Grøn O. A Revision of the Model for Dwelling Organisation in the Southern Scandinavian Mesolithic // L'Europe des derniers chausseurs. Ėpipaléolithique et Mésolithique. Paris, 1999. P.321-326; Skaarup J., Grøn O. Møllegabet II. P. 51-74. 

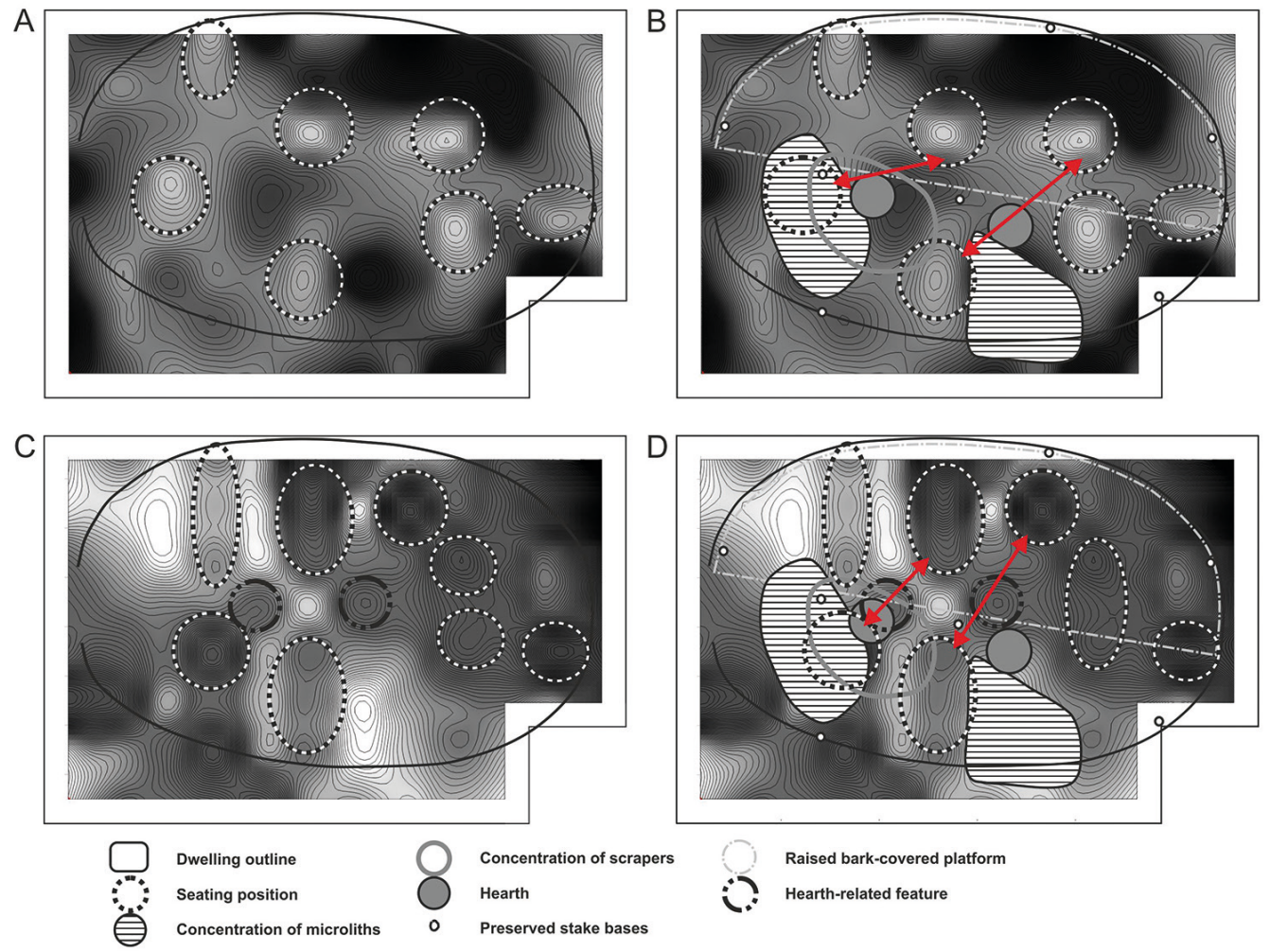

Fig. 5. The $3 \times 5 \mathrm{~m}$ dwelling at the submerged Møllegabet II site. A: The quotient $\mathrm{Q}_{3}=(\mathrm{A}$ pieces $) /$ (B pieces $+C$ pieces $+D$ pieces), where A pieces are $0<2 \mathrm{~cm}$, B pieces $2<4 \mathrm{~cm}$, C pieces $4<6 \mathrm{~cm}$ and $D$ pieces $\geq 6 \mathrm{~cm}$. The indicated seating places are shown. B: The same as $A$, showing the relation between the indicated seating places and the concentrations of microliths/arrowheads, the concentrations of scrapers, as well as the hearths, the stakes and the platform. The indicated seating places are shown, including two marked by black broken lines which are too close to the hearths to be counted as seating places. C: The quotient $\mathrm{Q}_{4}=\mathrm{G} /($ A pieces $+\mathrm{B}$ pieces $+\mathrm{C}$ pieces $+\mathrm{D}$ pieces), where $\mathrm{G}$ is the total weight of the debitage per square. This is the average weight of the pieces in each square. D: The same as $\mathrm{C}$, showing the relation between the indicated seating places and the concentrations of arrowheads, the concentrations of scrapers as well as hearths, stakes and the platform. Graphics: O. Grøn

tioning. This seems to indicate that the size/dimensions of the debitage pieces mattered more to the inhabitants of the prehistoric dwelling than their weight. It is important to note, however, that it is apparently also possible to obtain a useful result by just calculating the average debitage weight per square unit.

House 2 (A7681) at Tågerup has been interpreted by Cecilia Cronberg ${ }^{27}$ as a c. $14 \times 6 \mathrm{~m}$ longhouse. This interpretation is based on the configuration of the physical features related to the house, such as the $13 \mathrm{~m}$ long stone packing interpreted as a platform in the dwelling space and a series of postholes interpreted as supports for a central roof ridge (Fig. 6). As an alternative approach, the present study focusses on how the debitage patterns are distributed and fit into the physical frames in an attempt to obtain a better

27 Cronberg C. Husesyn. P. 82-155. 


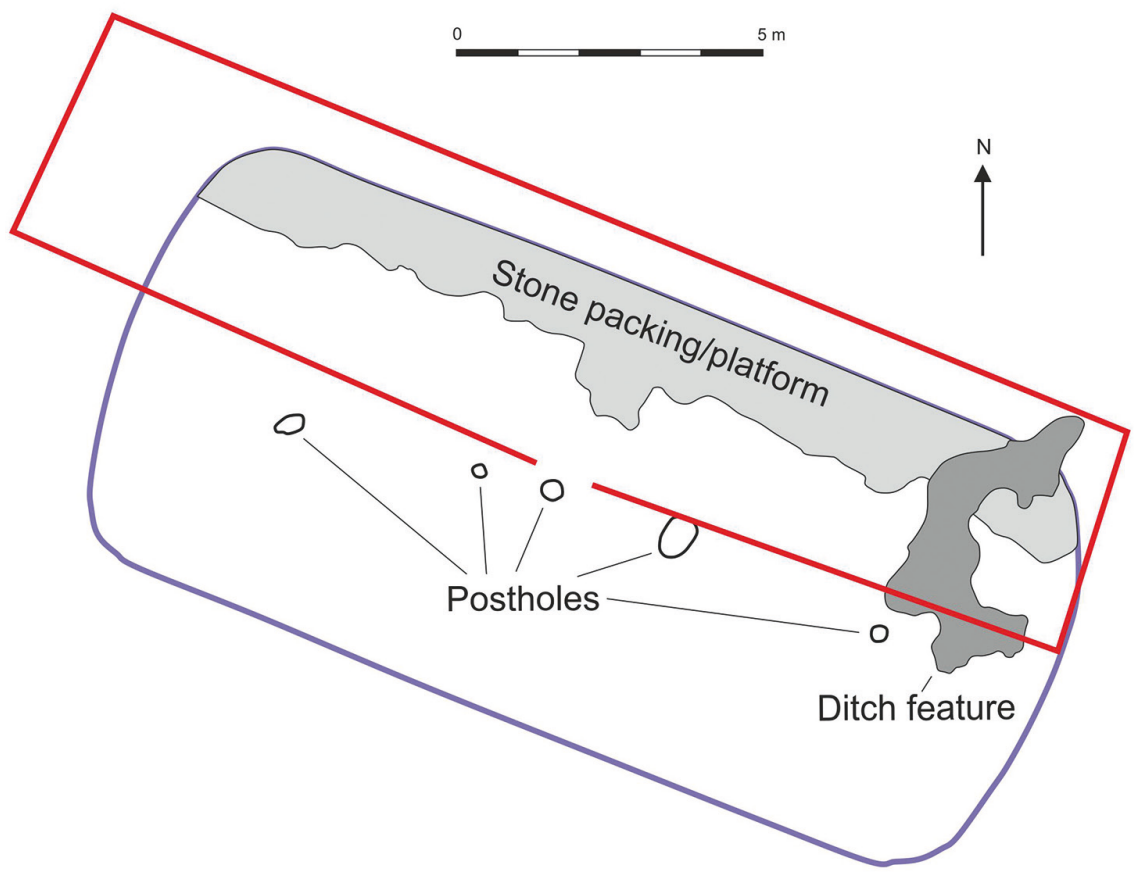

Fig. 6. Two different interpretations of the Tågerup 'longhouse.' Cronberg’s (2001) interpretation is shown with a blue line. This is based on the configuration of the physical features, such as the $13 \mathrm{~m}$ long stone packing/platform and a series of postholes interpreted as supports for a central roof ridge. An alternative interpretation, presented in this paper, shown with a red line, is based on a study of the debitage distribution patterns. Graphics: O. Grøn

understanding of the composition of such a potentially large Mesolithic household. The author has previously suggested that the development of quite large multi-family households in the Late Mesolithic represents an interesting social feature relative to subsequent 'Neolithisation'28.

As the recording of the debitage at this site renders a precise reconstruction difficult, and the number of well-defined tools, such as arrowheads, scrapers, knives etc. is so small that it does not show concentrations indicating the seating spaces of the central individuals in the household of this large dwelling, the average debitage weight was used instead to identify the seating spaces. This resulted in the detection of a row of six rather large, regularly spaced maxima on the stone packing and continuing approximately $3 \mathrm{~m}$ to the west of it. These maxima are of irregular oblong shape - similar to a couple of the maxima for average debitage weight at Møllegabet II — and are in some cases apparently composed of several conjoining maxima, potentially representing the seating spaces of several individuals (Fig. 7 B).

The debitage shows a significant oblong concentration south of the stone packing, which is so clearly delimited to the south that it must be taken as a strong indication of

${ }^{28}$ Grøn O. Mesolithic dwelling places in south Scandinavia. P. 685-708. 


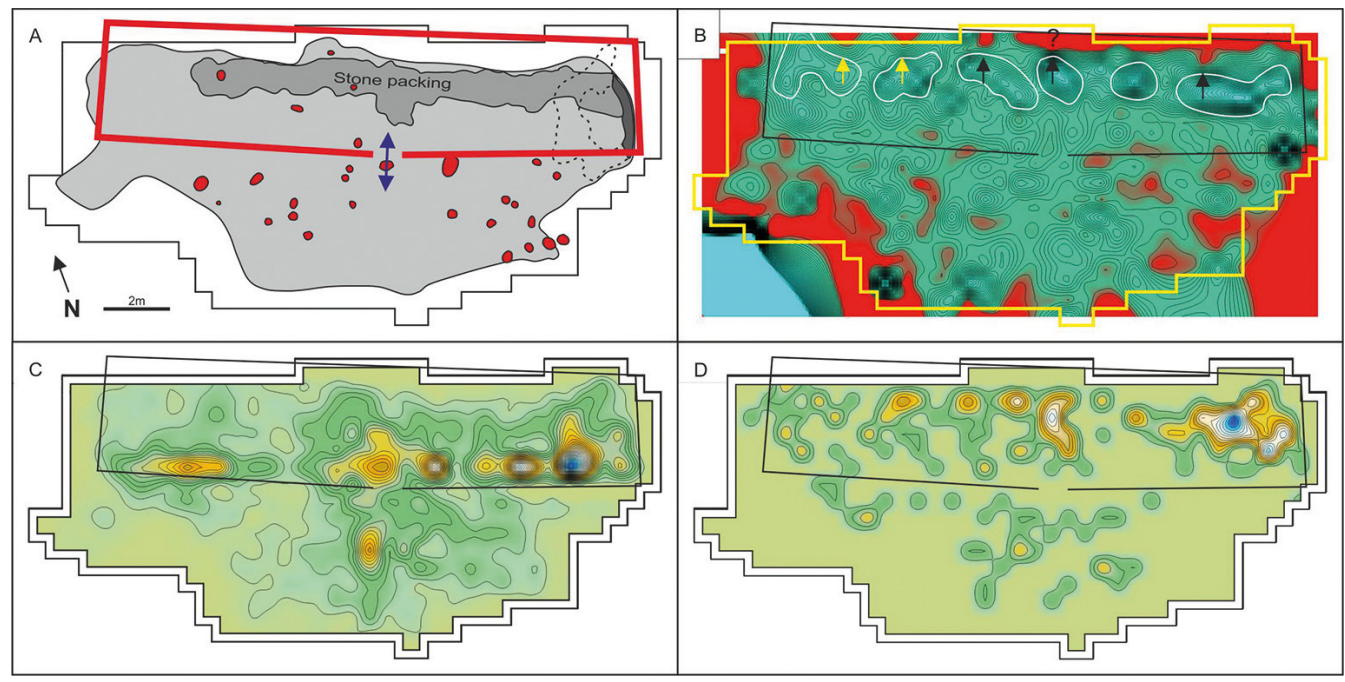

Fig. 7. The longhouse at Tågerup, Sweden. A: The up to $20 \mathrm{~cm}$ thick cultural deposits associated with the feature (light grey), the stone packing/platform (medium grey), the ditch structure (dark grey), the postholes (red rounded features), and the proposed revision of the house outline (red line). $B$ : The average weight of the debitage pieces quotient $Q_{4}=G /($ A pieces $+B$ pieces $+C$ pieces $+D$ pieces), where $\mathrm{G}$ is the total weight of the debitage per $0.25 \mathrm{~m}^{2}$ square. The yellow and black arrows mark the positions of the 'indentations' in the northern part of the quotient configuration. The contour lines mark the quotient levels of $0.3,0.6,0.9$ etc. per $0.25 \mathrm{~m}^{2}$ square. C: The distribution of the debitage as number of pieces per square unit with the contour lines marking the levels 100, 200, 300 etc. pieces per $0.25 \mathrm{~m}^{2}$ square. $\mathrm{D}$ : The distribution of cores with the contour lines marking the levels $0.5,1.0,1.5$ etc. pieces per $0.25 \mathrm{~m}^{2}$ square. Graphics: O. Grøn

a wall located immediately to the south of it. A central tongue extending further to the south represents a central breach in the barrier, which most likely reflects the position of an entrance (Fig. $7 \mathrm{C}$ ). If the stone packing is perceived as a platform, in accordance with Cronberg's interpretation ${ }^{29}$, the main part of the debitage - as at Møllegabet II - appears to be located immediately to the south of it. It is interesting that the cores (Fig. 7 D), the knapping stones and the seating spaces seem mainly to be located on the platform. This indicates that, while flintknapping appears to have been carried out in front of the platform, the knapping members of the household seem to have had their main seating spaces on it, probably together with their families, and that they stored their knapping stones and cores there when they were not knapping.

A series of interesting features are the 'indentations' evident on the northern side of the image depicting average debitage weight (arrowed in Fig. 7 B). The two westernmost indentations, marked with yellow arrows, lie partly outside the excavated area, but still reflect tendencies in the excavated debitage in the adjacent squares. The next three - the middle one of which is questionable - are marked with black arrows. These low-value indentations are areas dominated by small, light pieces of debitage. They could represent areas up to a 'rear wall' that were kept clean because they were used for storage of sleeping skins during the day. This is a typical position for storage of such items in hunter-gatherer

29 Cronberg C. Husesyn. P. 82-155. 


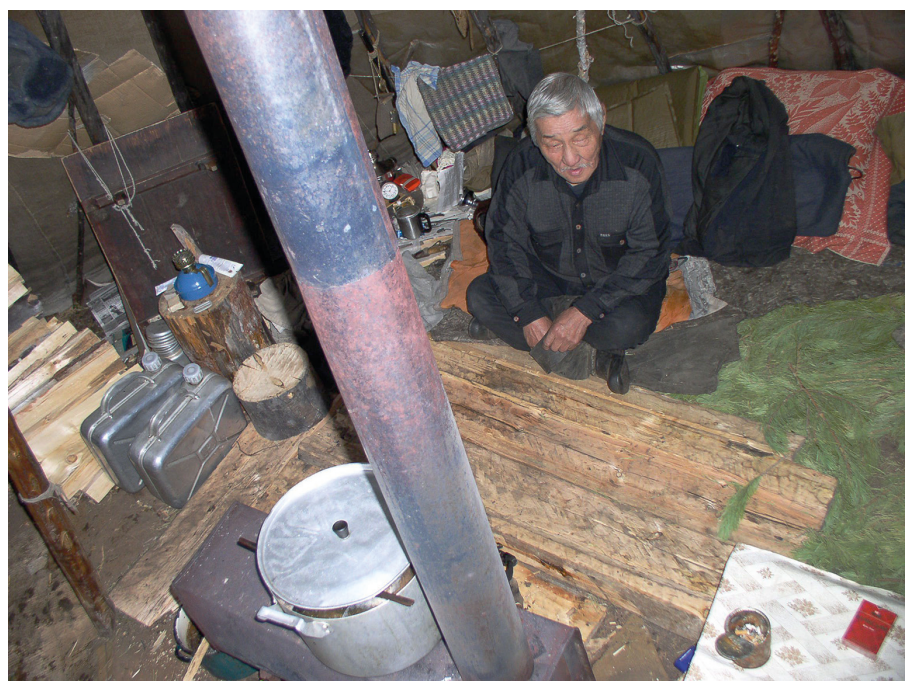

Fig. 8. Old Lasar Cichogir, the leader of the Cichogir clan in the Yerbogachen area, in the northern part of Irkutsk county, in 2005. $\mathrm{He}$ is sitting in the husband's position in his tent (the entrance is to his left). As is typical for Evenk tents, his sleeping skins are rolled up against the tent wall and covered by the reddish carpet. During the day, they can be used as a pillow when he wants a rest. Photo: O. Grøn

dwellings (e. g. Fig. 8). The position of the 'rear wall' of the house is fixed based on the assumption that there was a narrow zone alongside the back wall that was kept partly free of larger pieces of debitage. The ends of the house are fixed so they roughly follow the decline in debitage weight (Fig. 7 B).

The present reconstruction ignores the postholes as representing structural features related to the longhouse. They are assumed instead to have had other functions (storage platforms etc.) in the area with many activities outside its entrance. The house itself is presumed to have had log walls.

The spatial situations in the two Early Ertebølle dwellings indicate that the most active flintknapping members of the households had seating spaces on the floor, below the platforms, when they were knapping and possibly undertaking other dirty activities, as the Møllegabet dwelling indicates. In other situations, such as the one evident in the Tågerup longhouse, they seem to have had a seating space on the platform adjacent to those of their family members. They seem consequently to have switched between two seating positions, one of which roughly conjoined with their sleeping position on the platform. This is in good accordance with the reconstruction of Ertebølle spatial etiquette based on the Møllegabet site (Fig. 1) ${ }^{30}$.

As in some other Late Mesolithic dwellings, the identification of hearths is not obvious. Cronberg ${ }^{31}$ suggests a single central hearth, based on a central concentration of burnt flint. It is necessary to be aware, however, that the Ertebølle culture apparently had a preference for smoke-free heating of its dwellings using blubber lamps, which when

${ }^{30}$ Skaarup J., Grøn O. Møllegabet II. P. 41-74.

31 Cronberg C. Husesyn. P. 82-155. 
handled in the right way produce very little smoke ${ }^{32}$. In conjunction with this, it should be considered whether the many more or less burnt 'cooking stones' found in Late Mesolithic dwellings, which were apparently often heated on hearths outside the buildings, could also have served as heat sources, thereby leaving few traces of charcoal ${ }^{33}$. Heat sources such as these, located at the front of the platform for each family unit, as reconstructed for the Tågerup longhouse in Fig. 1, would provide more evenly distributed heating and fit the pattern seen in the Møllegabet II dwelling (Fig. 5 B).

\section{Discussion}

The Hjemsted dwelling is interesting because, given its extremely limited lithics content, it represents a class of Maglemose site that, in the absence of good organic preservation and well-preserved physical features, would be easily overseen during an archaeological survey. Sites of this kind seem to represent a greater problem than hitherto assumed ${ }^{34}$. The dwelling was recognised during a large-scale Iron Age excavation solely due to its rather well-preserved tent ring of large stones and a well-defined $22 \mathrm{~cm}$ deep dwelling pit. It was excavated by Per Ethelberg and the author of the article in $0.25 \mathrm{~m}^{2}(0.5 \times 0.5 \mathrm{~m})$ squares. As the finds assemblage contains no date-conferring artefacts and only an extremely small amount of debitage, it also demonstrates the spatial-analytical problems associated with Mesolithic dwellings containing few knapped lithics. As no charcoal was available for radiocarbon dating, TL and subsequently OSL dating of the same sample from the dwelling pit - based on the exposure to light of the material in it - was used to confirm the expected date in the Maglemose culture, around 7100 BC (R-862701 - TL: 7800 BC \pm 700 , OSL: $6600 \pm 500)^{35}$.

The average flint density of only 8.5 pieces per $\mathrm{m}^{2}$ (Fig. 10) seen here is too low to allow for the application of debitage analysis. The site does, however, have an area with relatively high values for burnt flint (Fig. $9 \mathrm{~B}$ ), and to the south of this there is a small concentration of debitage (Fig. 9 A). It is assumed that the former, the hearth, represents the female activity zone, while the latter, the debitage concentration, represents the male activity zone, without microliths. These two distribution features occupy their correct positions in this beautiful little Maglemose dwelling with a dwelling pit encircled by a tent ring of larger stones (Fig. 9 C).

It is obvious that the formulas for sites with low debitage densities do not work for all Mesolithic dwellings. However, it is important that in the cases where the formulas do appear to work well, the results support the previous interpretations of the organisation

32 Egede H. A Description of Greenland by Hans Egede, who was a Missionary in that Country for twenty-five Years. London, 1818. P.113-118; Heron C., Andersen S., Fischer A. et al. Illuminating the Late Mesolithic: residue analysis of 'blubber' lamps from Northern Europe // Antiquity. 2013. Vol.87 (335). P. 178-188; Mathiassen T. Blubber Lamps in the Ertebølle Culture // Acta Archaeologica. 1935. Vol. VI (12). P. $139-152$.

33 See, e. g.: Andersen S. H. Vængesø and Holmegaard. Ertebølle Fishers and Hunters on Djursland. Aarhus, 2018. P. 19, 221-226; Grøn O., Sørensen S. An inland site from the early Kongemose. P. 7-18; Hernek R. Mesolitiska härdar i Västsverige och södra Norge. När, var, hur och lite varför // Arkeologi i Tanums Världsarv. Åttatusen år i Tanum utifrån sex arkeologiske undersökninger för väg E6. Tågerup, 2016. P. 1966; Larsson L. Of House and Hearth. P. 197-209; Larsson M. Life and Death in the Mesolithic of Sweden. Oxford, 2017; Sørensen S. A. Lollikhuse - a Dwelling Site under a Kitchen Midden. P. 19-29.

${ }^{34}$ Grøn O., Peeters H. Mesolithic 'ghost' sites and related Stone Age problems with lithics.

35 Grøn O. The Maglemose Culture. P. 69-70. 


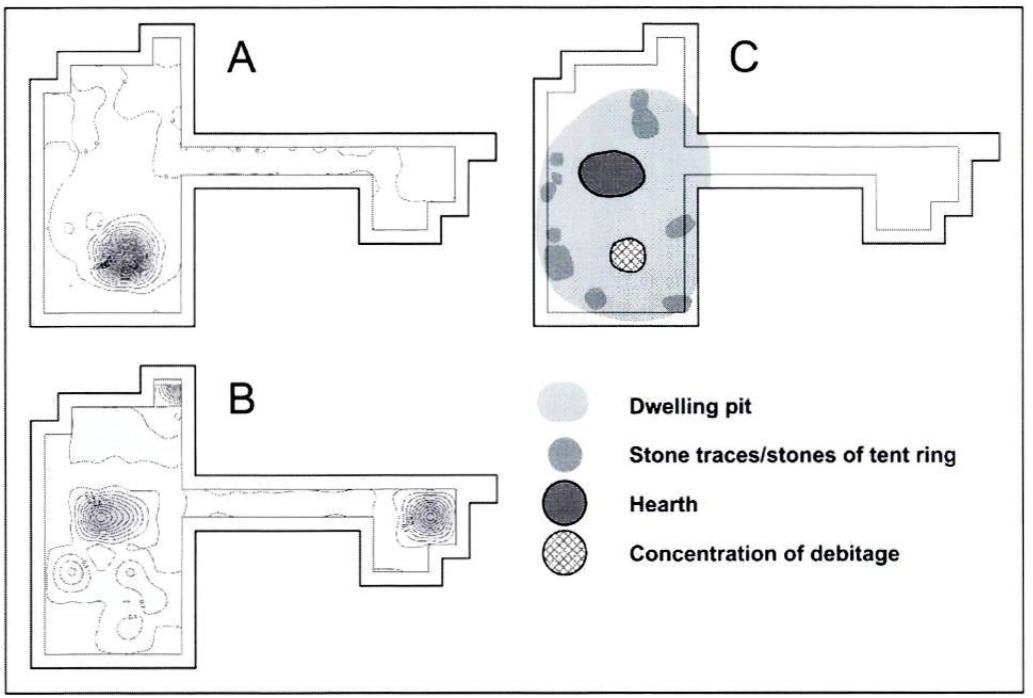

Fig. 9. The Hjemsted site. A: The debitage concentration with equidistant contour lines for the values $0,5,10$ etc., showing one small concentration. B: The burnt debitage divided by the total number of debitage pieces per $0.15 \mathrm{~m}^{2}$ square, with equidistant contour lines for the values $0,0.1,0.2$ etc., showing one small concentration. C: The spatial relationship between the dwelling, the hearth and the concentration of debitage. Graphics: O. Grøn

Average flint debitage per square meter dwelling area

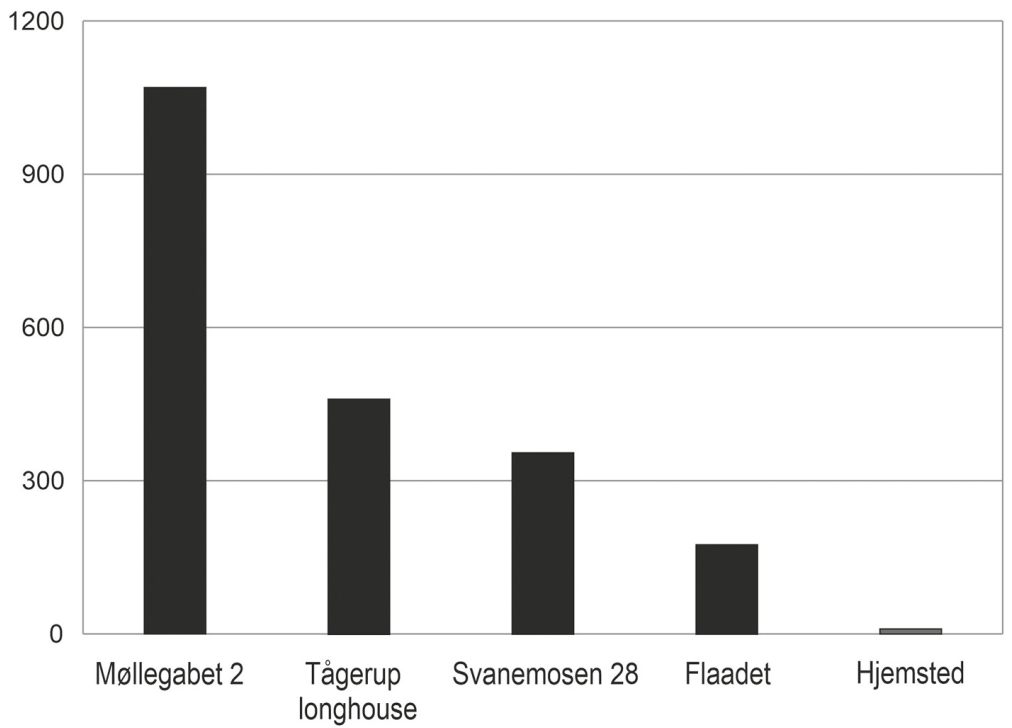

Fig. 10. The average densities of debitage within the dwelling areas discussed in the paper. Graphics: O. Grøn 
of the dwelling spaces. As seen above, the debitage analysis reinforces the conclusion that there appear to have been both single- and two-family dwellings during the Maglemose culture, with the latter being spatially organised as 'mirrored' versions of the former ${ }^{36}$. In the case of the Tågerup longhouse, it also appears to provide new details about the internal arrangement and, consequently, the household, in a way that concurs well with what can be inferred from the available ethnographic data ${ }^{37}$.

It is important to be aware that the analysis of spatial debitage patterns is a rough approach which must be adapted to the way in which the material has been recorded at the different sites. Several formulas can be applied. The important aspect is that they can produce an image of the relative distribution of small/large or light/heavy debitage pieces.

If we are to understand the cultural-environmental interactions of prehistoric hunter-gatherer societies at something deeper than a general level, it is necessary to obtain detailed information on the economy of these societies, including how social groups (clans?) placed their members within their territories at different times of the year ${ }^{38}$. The analytic approach employed here appears to make it possible to obtain important information about the prehistoric households from dwellings that contain a sufficient amount of lithic debitage, which can, in turn, be extrapolated to those dwellings lacking this lithic material but which can be recognised using other parameters. This appears to be the only reliable method of gaining information about gender roles from prehistoric live situations, in that it enables us to isolate and identify male and female activity zones in the dwellings, which reflect the general culture-specific spatial organisational rules. The resulting picture still lacks the children who, understandably enough, do not seem to be reflected in a systematic way in the spatial organisation of activities. This problem can hopefully be solved in some time so that we can form the full picture of the prehistoric households and the variations within this.

\section{References}

Andersen S. H. Veengesø and Holmegaard. Ertebølle Fishers and Hunters on Djursland. Aarhus, Aarhus University Press, 2018, 285 p.

Åstveit L.I. Different ways of building, different ways of living: Mesolithic house structures in western Norway. Mesolithic Horizons, vol.I. Oxford, Oxbow Books, 2009, pp. 415-421.

Bagniewski Z. Obozowisko mezolityczne we wsi Siedlisko, woj. zielonogórskie, stan. 16. Światowit, 1982, vol.XXXV, pp. 5-54.

Bērziņš V. Sārnate: Living by a Coastal Lake During the East Baltic Neolithic. Oulu, Oulun Yliopisto, 2008, $473 \mathrm{p}$.

Clarke D. V., Sharples N. Settlements and Subsistence in the Third Millenium BC. The Prehistory of Orkney. Edinburgh, Edinburgh University Press, 1990, pp. 54-82.

Conneller C., Milner N., Taylor B., Taylor M. Substantial settlement in the European Early Mesolithic: new research at Star Carr. Antiquity, 2012, vol. 86 (334), pp. 1004-1020.

Cronberg C. Husesyn. Tågerup specialstudier. Riksantikvarieämbetet, Avdelingen för arkeologiske undersökninger UV Syd, 2001, pp. 82-155.

Egede H. A Description of Greenland by Hans Egede, who was a Missionary in that Country for Twenty-five Years. London, T. and J. Allman, 1818, 347 p.

36 Grøn O. The Maglemose Culture. P. 45-56.

37 Ibid. P.7-9.

38 Grøn O. Optimal foraging or not? An Evenk example of resource exploitation // Stratum Plus. 2017.

No. 1. P.319-328. 
Engelstad E. The Iversfjord locality. A study of behavioral patterning during the late Stone Age of Finnmark, North Norway, vol.XIX. Tromsø, Tromsø Museums Skrifter, 1981, 176 p.

Grøn O. A 7000 year old Mesolithic dwelling with a brush floor excavated under water. A window into behavioural organization of hunter-gatherer dwellings. Site-internal spatial organization of hunter-gatherer societies: Case studies from the European Palaeolithic and Mesolithic. Papers submitted at the session (C58) "Come in ... and find out: Opening a new door into the analysis of hunter-gatherer social organisation and behaviour", held at the $15^{\text {th }}$ U. I. S. P. P. Conference in Lisbon, September 2006. Mainz, Verlag des Römisch-Germanischen Zentralmuseums, 2011, pp. 249-261.

Grøn O. A method for reconstruction of social organization in prehistoric societies and examples of practical application. Social Space. Proceedings of an Interdisciplinary conference on human spatial behaviour in dwellings and settlements. Odense, Odense University Press, 1991, pp. 100-117.

Grøn O. A Revision of the Model for Dwelling Organisation in the Southern Scandinavian Mesolithic. L'Europe des derniers chausseurs. Épipaléolithique et Mésolithique. Paris, Ėditions du CTHS, 1999, pp. 321-326.

Grøn O. Aggemose - part II. Refitting and indications of wall effect. Journal of Danish Archaeology, 1994, vol. 12, pp.7-12.

Grøn O. Analyse af flintspredninger på bopladser (chapter of university text book). Flintstudier. En håndbog $i$ systematiske analyser af flintinventarer. University textbook about flint. Århus, Århus University Press, 2000, pp. 157-186.

Grøn O. Bum-spaces in Mesolithic debitage distributions - Positions adopted by individuals in dwellings as indicated by artefact concentrations. Studies dedicated to prof. Lucyna Domanska at the $45^{\text {th }}$ anniversary of her scientific and didactic work and on her $70^{\text {th }}$ birthday. Lodz, The Institute of Archaeology, University of Lodz, 2018, pp.73-87.

Grøn O. Interdisciplinary reflections on repetitive distribution patterns in Scandinavian Mesolithic dwelling spaces. Journal of Archaeological Science: Reports, 2018, vol. 18, pp.925-935.

Grøn O. Mesolithic dwelling places in south Scandinavia: their definitions and social interpretation. Antiquity, 2003, vol. 77 (298), pp. 685-708.

Grøn O. Optimal foraging or not? An Evenk example of resource exploitation. Stratum Plus, 2017, no. 1, pp. 319-328.

Grøn O. Seasonal variation in Maglemosian group size and structure: A new model. Current Anthropology, 1987, vol. 28 (3), pp. 303-327

Grøn O. Studies in Settlement Patterns and Submarine Bogs: Results and Strategy for Further Research. Contributions to the Mesolithic in Europe. Papers Presented at the Fourth International Symposium 'The Mesolithic in Europe', Leuven 1990. Leuven, Leuven University Press, 1990, pp. 81-86.

Grøn O. The Maglemose Culture. The reconstruction of the social organization of a mesolithic culture in Northern Europe. Oxford, Archaeopress, 1995, 99 p.

Grøn O., Kuznetsov O. Ethno-archaeology among Evenkian forest hunters. Preliminary results and a different approach to reality! Mesolithic on the Move. Papers presented at the Sixth International Conference on the Mesolithic in Europe. Stockholm, Oxford, Oxbow Books, 2003, pp.216-221.

Grøn O., Sørensen S. An inland site from the early Kongemose Culture. Journal of Danish Archaeology, 1993, vol. 11 (1), pp. 7-18.

Hernek R. Mesolitiska härdar i Västsverige och södra Norge. När, var, hur och lite varför. Arkeologi i Tanums Världsarv. Åttatusen år i Tanum utifrån sex arkeologiske undersökninger för väg E6. Tågerup, Bohusläns Museums förlag, 2016, pp. 19-66.

Hernek R. Nytt ljus på Sandarnekulturen. Om en boplats från äldre stenåldern i Bohuslän. Göteborg, Göteborgs universitet, Institutionen för arkeologi, 2005, 386 p.

Heron C., Andersen S., Fischer A., Glykou A., Hartz S., Saul H., Steele V., Craig O. Illuminating the Late Mesolithic: residue analysis of 'blubber' lamps from Northern Europe. Antiquity, 2013, vol. 87 (335), pp. 178-188.

Karsten P., Knarrström B. The Tågerup Excavations. Lund, National Heritage Board, 2003, 254 p.

Katiskoski K. The semisubterranean dwelling at Karmelahti in Puumala, Savo province, eastern Finland. Huts and Houses: Stone Age and Early Metal Age Buildings in Finland. Jyvaskyla, National Board of Antiquities, 2002, pp. 171-200. 
Kind C.-J. Einraum-Wohnung mit Aussenlage: Das grosse Mesolithische Hauptlager aus dem Horizont III von Siebenlinden. Pleistocene Foragers: Their Culture and Environment. Festschrift in Honour of Gerd-Christian Weniger for his Sixtieth Birthday, vol. 6: Mettmann. [N.1.], Wissenschaftliche Schriften des Neanderthal Museums, 2013, pp. 133-162.

Larsson L. A contribution to the knowledge of Mesolithic huts in southern Scandinavia. Meddelande från Lunds Universitets Historiske Museet 1973-1974. Lund, Lunds Universitets Historiske Museet, 1975, pp. 5-28.

Larsson L. Of House and Hearth. The Excavation, Interpretation and Reconstruction of a Late Mesolithic House. Archaeology and Environment, 1985, vol. 4, pp. 197-209.

Larsson L., Sjöström A. Hut and House Structures in the Mesolithic of Southern Scandinavia. Site-internal spatial organization of hunter-gatherer societies: Case studies from the European Palaeolithic and Mesolithic. Site-internal spatial organization of hunter-gatherer societies: Case studies from the European Palaeolithic and Mesolithic. Papers submitted at the session (C58) "Come in ... and find out: Opening a new door into the analysis of hunter-gatherer social organisation and behaviour", held at the $15^{\text {th }}$ U. I. S. P. P. Conference in Lisbon, September 2006. Mainz, Verlag des Römisch-Germanischen Zentralmuseums, 2011, pp. 233-247.

Larsson M. Bredasten - An Early Ertebølle Site with a Dwelling Structure in South Scandinavia. Meddelande från Lunds Universitets Historiske Museet 1985-1986. Lund, Lunds Universitets Historiske Museet, 1986, pp. 25-51.

Larsson M. Life and Death in the Mesolithic of Sweden. Oxford, Oxbow Books, 2017, 144 p.

Larsson R. Inledning. Tågerup specialstudier. Riksantikvarieämbetet, Avdelingen för arkeologiske undersökninger, UV Syd, 2001, pp. 15-31.

Lass Jensen O. Dwellings and graves from the Late Mesolithic site of Niva 10, eastern Denmark. Mesolithic Horizons, vol.I. Oxford, Oxbow Books, 2009, pp.465-472.

Mathiassen T. Blubber Lamps in the Ertebølle Culture. Acta Archaeologica, 1935, vol. VI, no. 1-2, pp. 139152.

Molin F. Along the shores of the Ancylus Lake. Trädgardstorp and other coastal Mesolithic settlement sites during the Late Ancylus period in western Östergötland. Mesolithic Horizons, vol.I. Oxford, Oxbow Books, 2009, pp. 458-464.

Molin F., Hagberg L., Westermark A. Living by the shore: Mesolithic dwellings and household in Motala, eastern central Sweden, 5600-5000 cal. BC. Journal of Archaeological Science: Reports, 2018, vol. 18, pp. 913-924.

Ramstad M. Island settlements and maritime hunter-fishers: spatial and temporal transformations over 11,000 years at Melkøya, northern Norway. Mesolithic Horizons Mesolithic Horizons, vol.I. Oxford, Oxbow Books, 2009, pp. 422-429.

Skaarup J. Flaadet. En tidlig maglemoseboplads på Langeland. Langeland, Meddelelser fra Langelands Museum, 1979, $146 \mathrm{p}$.

Skaarup J., Grøn O. Møllegabet II. A submerged Mesolithic settlement in southern Denmark. Oxford, Archaeopress, 2004, 209 p.

Sørensen S. A. A Maglemosian Hut at Lavringe Mose, Zealand. Journal of Danish Archaeology, 1988, vol. 6, pp. 53-62.

Sørensen S. A. Lollikhuse - a Dwelling Site under a Kitchen Midden. Journal of Danish Archaeology, 1995, vol. 11, pp. 19-29.

Wenzel S. Behausungen im Späten Jung-paläolithikum und im Mesolithikum in Nord-, Mittel- und Westeuropa. Mainz, Verlag des Römisch-Germanischen Zentralmuseums, 2009, 183 p.

Статья поступила в редакцию 22 июля 2020 г. Рекомендована в печать 25 мая 2021 г.

Received: July 22, 2020

Accepted: May 25, 2021 